\title{
Ambientalismo e Liberdade
}

\author{
Environmentalism and Liberty
}

\section{Ambientalismo y Libertad}

\author{
Edu Silvestre de Alburqueque ${ }^{1}$ \\ Isonel Sandino Meneguzzo²
}

\begin{abstract}
RESUMO: A presente nota trata de uma abordagem conservadora do meio ambiente, associada à ideia de liberdade e pleno desenvolvimento humano. Recuperamos uma série de casos paradigmáticos de responsabilidade social dos proprietários rurais e industriais pelo meio ambiente, que demonstrem a necessidade de internalização dos custos ambientais ao processo produtivo. Esperamos demonstrar, assim, que as chamadas questões ambientais podem ser abordadas diante de uma perspectiva social conservadora.
\end{abstract}

PALAVRAS-CHAVE: Conservadorismo. Ambientalismo. Liberdade.

ABSTRACT: This note present a conservative approach to the environment, associated with the idea of freedom and full human development. We recover a series of paradigmatic cases of social responsibility of the rural and industrial owners by the environment, and also that demonstrate the need to internalize the environmental costs to the productive process. We hope to demonstrate, therefore, that the called environmental issues can be addressed with a conservative social perspective.

KEY WORDS: Conservatism. Environmentalism. Liberty.

RESUMEN: La presente nota trata de un enfoque conservador del medio ambiente, asociado a la idea de libertad y pleno desarrollo humano. Recuperamos una serie de casos paradigmáticos de responsabilidad social de los propietarios rurales e industriales y por el medio ambiente, y también que demuestren la necesidad de internalización de los costos ambientales al proceso productivo. Esperamos demostrar, así, que las llamadas cuestiones ambientales pueden ser abordadas ante una perspectiva social conservadora.

PALABRAS-CLAVE: Conservatismo. Ambientalismo. Libertad.

\footnotetext{
1 Professor do Departamento de Geografia e do Programa de Pós-Graduação em Geografia da Universidade Federal do Rio Grande do Norte (UFRN). Av. Senador Salgado Filho, 3000 - BR101 KM 92, Lagoa Nova, Natal/RN - CEP 59078970. edusilvestrealbuquerque@bol.com.br.

2 Professor Adjunto do Departamento de Geociências da Universidade Estadual de Ponta Grossa e do Programa de Pós Graduação em Geografia. Av. Bonifácio Viléla - Centro, Ponta Grossa - PR, 84010-330. imeneguzzo@hotmail.com.
} 
A geração passada era indubitavelmente algo mais "vermelha" que "verde", significando isto que os ideais humanistas estavam acima de qualquer outro. Prova disto, União Soviética e diversos países do Leste Europeu, embora socialistas, desenvolveram áreas industriais de elevadas emissões de poluentes e sistemas agrícolas em larga escala e intensivos em produtos químicos. O nacional-bolchevismo, o leninismo e o stalinismo se sucederam na União Soviética com base no mesmo princípio: o nacionaldesenvolvimentismo. Mas, em paralelo com o processo de solapamento do socialismo real, ocorre uma mudança substancial no pensamento crítico que inverte as prioridades no pensamento da atual geração, agora algo mais "verde" que "vermelho". Evidente que tanto na época atual quanto outrora, cada corrente hegemônica de pensamento acredita que sua "cor" ou visão de mundo contenha todos os elementos da liberdade, afinal, ninguém se vê parcial. A questão que colocamos em discussão é acerca da possibilidade de uma terceira visão, simultaneamente humanista e ambientalista, bem como se esta pode ser representada pela visão de mundo e propostas da filosofia política conservadora.

Roger Scruton (2015) destaca que o conservadorismo de Edmund Burke parte de uma conexão necessária entre os vivos, os mortos e os que estão por nascer; que não existe nada mais importante para os seres humanos que construir um lar e deixar como legado para os filhos. Na promessa conservadora, a Oikophilia, o amor pelo lar, serve também à causa do ambientalismo, mas inova ao acreditar numa associação entre vizinhos ao invés das ações verticalizadoras do Estado.

Infelizmente, prossegue o autor, "[...] a causa conservadora foi poluída pela ideologia do grande capital, por ambições globais das empresas multinacionais e pela supremacia da economia sobre o pensamento dos políticos modernos" (SCRUTON, 2015, p. 109). Então, removida essa camada de ideologia, talvez possamos enxergar o genuíno conservadorismo e suas possibilidades de emprego nas políticas ambientais em particular e na questão da crise civilizacional em geral.

Estamos direcionados em demasiado para problemas ambientais em escala global aquecimento global, diminuição da camada de ozônio, extinção de espécies em massa, derretimento das calotas polares, radioatividade - tudo fora do alcance de qualquer governo nacional, e cujas tentativas de costura de tratados internacionais tem logrado pouco êxito. Esse malogro dos planos internacionalistas radicais deriva dos altos custos envolvidos (e no compartilhamento desses custos), da falta de tecnologias alternativas de baixo custo 
(sobretudo para superar a economia do carbono) e dos riscos à soberania dos Estados (SCRUTON, 2015).

A abordagem política da questão ambiental está visivelmente equivocada, pois quase sempre a falta de regulamentação e efetividade não é global, mas nacional, regional e local. Assim, se cada nação e cada municipalidade encaminhassem corretamente seus próprios problemas ambientais, seguramente nosso planeta seria um melhor lugar de se viver.

Ao contrário do senso comum, os problemas ambientais não são causados pelas grandes madeireiras e mineradoras; eles surgem de nossos hábitos "[...] de desfrutar os benefícios das atividades e de transferir os custos", então o meio ambiente é degradado porque "[...] externalizamos os custos daquilo que fazemos" (SCRUTON, 2015, p. 110).

Acerca da degradação ambiental, a produção é resultado; e a causa reside numa economia livre ou sem regulação eficaz: "Sempre que viajamos de avião, vamos ao supermercado ou consumimos combustíveis fósseis estamos exportando os nossos custos para terceiros e para as futuras gerações." (SCRUTON, 2015, p. 110).

O ponto de intersecção entre ambientalistas e conservadores está no amor à Terra, no sentido de lar ou lugar, onde "[...] as lealdades e as preocupações locais devem ter um espaço apropriado na tomada de decisão se quisermos combater os efeitos negativos da economia global" (SCRUTON, 2015, p. 111). Os projetos locais quando bem formulados e geridos são vistos pelos cidadãos como algo "nosso" e não de uma organização não governamental ou organismo internacional:

Penso nos voluntários e ativistas que se propuseram a proteger o ambiente
natural da Grã-Bretanha no século XIX; o English National Trust, uma
associação civil com 4 milhões de membros dedicada a conservar a zona
rural e os povoados; a iniciativa de americanos, verdadeiros amantes da
natureza, que atuam junto ao Congresso dos Estados Unidos para criar
parques nacionais; a atuação da Islândia para proteger os criadouros do
bacalhau do Atlântico; a legislação que libertou a Irlanda do uso de sacolas
de polietileno; as iniciativas na área de energia limpa na Suécia e na
Noruega; as leis de planejamento da Suíça que permitiram às comunidades
locais manter o controle sobre seu meio ambiente e administrá-lo em regime
de posse compartilhada; as políticas britânicas de "Cinturão Verde" que
levaram ao fim da expansão urbana; as iniciativas dos pescadores de
lagosta no Maine e de bacalhau na Noruega para estabelecer uma
autorregulação na indústria da pesca comandada por gente local.
(SCRUTON, 2015, p. 112).

O autor cita ainda o caso da tradição jurídica inglesa cuja legislação vai ao encontro da responsabilização civil, a chamada common law. A sociedade civil em conjunto com um legislativo responsável, adapta e administra a mudança no meio ambiente de acordo com os interesses dos membros:

A proteção ambiental foi incorporada à legislação inglesa em 1865 com o leading case no processo Rylands contra letcher. Estabeleceu-se um 
regime de responsabilidade civil objetiva, de modo que aquele cuja atividade provocou um dano deverá indenizar as vítimas. Era uma decisão dos tribunais sob os princípios do common law e não uma tarefa do Parlamento. [...] um século mais tarde [...] a Associação dos Pescadores usou os princípios do common law para conseguir uma decisão contra os maiores poluidores do rio, que eram os governos locais e os distribuidores de energia nacionalizados. Em geral, devemos estar cientes quanto à prevenção desses preciosos instrumentos legais que já possuímos [...] subordinados aos princípios da igualdade e da lei natural e não de uma legislação hierarquicamente descendente. (SCRUTON, 2015, p. 113-114).

Em síntese, os conflitos relativos ao meio ambiente surgem da base, logo as soluções políticas também deveriam ser moldadas por causas de pessoas reais e não a partir de escritórios climatizados em Nova lorque, Bruxelas ou Brasília.

Mas a partir deste ponto do texto saímos do terreno seguro das citações do trabalho de Scruton, para problematizarmos algumas questões onde talvez o próprio autor se perca na trilha do pensamento conservador. No Brasil e em boa parte do mundo, a política ambiental e a política indígena adotaram o modelo norte-americano de reservas. A ideia de espaço protegido, estabelecida pelo Sistema Nacional de Unidades de Conservação, adquire tamanha força nessas políticas que é desestimulada qualquer alteração paisagística, ainda que decorrentes de necessidades relacionadas à subsistência.

Nas reservas indígenas, por sua vez, se há alguma integração entre homem e natureza (algo em si incerto à medida que essa relação se dá cada vez mais pela paisagem e não pela primeira natureza), predomina a vontade antropológica de isolar o indígena em áreas demarcadas. Este isolamento provoca, quase sempre, efeitos colaterais danosos, porque a história evolutiva da humanidade registra a riqueza dos contatos entre seus diversos grupos. O indígena não é uma peça viva de museu, nem um animal de zoológico que ganha um espaço maior que a jaula (aliás, a própria ideia de safari já tem abolido os zoológicos em muitos lugares civilizados), mas um ser social que interage e busca desenvolvimento em todos os aspectos.

De forma análoga, a necessidade de reforma agrária pode parecer algo evidente, mas ainda assim é preciso primeiro perguntar às pessoas da periferia se querem voltar ao campo e qual é esse campo que elas desejam. A reforma agrária talvez se coloque na vida dessas pessoas mais como uma alternativa à desesperança e resignação, do que como uma aspiração no sentido da liberdade desejada. De fato, talvez o sonho dessas pessoas hoje isoladas na Amazônia, assim como dos próprios sem-terra, seja que seus filhos tenham uma carreira médica ou nas engenharias e que a família tenha acesso às utilidades domésticas que auxiliem nas tarefas muitas vezes enfadonhas do lar, algo não muito diferente de nossas aspirações.

São essas perguntas acima que devemos fazer aos povos da floresta. Nos Estados Unidos o modelo de reservas foi aplicado em pequenas áreas remanescentes de vegetação 
nativa e numa situação de reduzida população indígena e talvez guiado pela ideia autoritária de confinamento de certos grupos sociais. No Brasil, esse modelo foi reproduzido de forma ampliada e cobre hoje parte significativa do território nacional, mas reproduz o mesmo plano autoritário de confinamento e de cumprimento de regras ambientais rígidas, ainda que o discurso seja de proteção.

Os apoiadores dessas políticas acreditam que estamos preservando culturas e integrando homem e natureza e alguns falam abertamente na criação de espaços livres do capitalismo no Brasil. Mas poucas vozes dizem que são espaços que também excluem o índio da modernidade, onde mesmo a implantação de alguns equipamentos coletivos por política pública ou de alguma organização não governamental não resolve os problemas típicos de guetos, de todo inviabilizadora de uma integração autônoma do indígena à sociedade. $\mathrm{O}$ isolamento quase nunca liberta, mas quase sempre aprisiona e limita. Pode-se citar como exemplo o caso da reserva Raposa Serra do Sol onde houve o comprometimento de aproximadamente $46 \%$ das terras do estado de Roraima e isolou cerca de 17 mil indígenas que ali vivem numa gigantesca área de 1,7 milhão de hectares. Sem recursos, o governo estadual não terá como levar melhorias aos indígenas (se levar energia a companhia elétrica poderá abrir falência, pois os indígenas não são obrigados a pagar a energia). À época da implantação da reserva, muitos índios se colocaram contrários em razão do fechamento das fazendas de arroz que geravam atividades remuneradas aos índios.

Se nós podemos decidir ser outra coisa e optar por lugares diferentes, ao indígena o único "direito" contido nas atuais políticas públicas é de permanecer indígena por toda a sua existência e no mesmo lugar. Mas numa situação ainda pior que a do sem-terra que luta por um assentamento, o indígena não desiste de um futuro enquanto conjunto de possibilidades não apenas para si mesmo, mas também para seus filhos e netos. Será isto mesmo que o índio deseja?!

Quando se fala em indígena não se trata de um tipo ideal, mas de situações diversas e complexas que abrangem tanto o índio que mora numa comunidade urbanizada quanto aquele que mora em áreas de difícil acesso e isto ocorre mesmo se tratando da Amazônia.

Curiosamente, políticos de esquerda e de direita e segmentos do movimento ambientalista têm confluído quando se trata da implantação de reservas indígenas e ambientais. Diante da falta de vontade ou da impossibilidade de nossos políticos reintegrarem o homem à natureza - considerando que ambos defendem políticas de industrialização a qualquer preço e de desenvolvimento da agropecuária em larga escala adotam então "espaços de preservação" como vitrine. Dessa forma, fora desses espaços que é justamente onde vive a maior parte da população - prosseguem freneticamente com o progresso material em curso. 
A Amazônia Legal representa mais da metade do território nacional em extensão territorial (IBGE, 2017), onde vivem hoje mais de 24 milhões de brasileiros e cuja taxa de crescimento demográfico é o dobro da média nacional. Embora a Amazônia não seja uma coleção de árvores, mas justamente um espaço já humanizado, costumeiramente os amazônidas são esquecidos nos discursos acadêmicos e políticos. Com efeito, esses milhões de amazônidas querem o mesmo que os demais brasileiros: asfalto, energia elétrica, alimentos, bens de consumo, postos de saúde, escolas e cidades modernas.

Nazira Camely (2011) estudou a situação das famílias que moram na Reserva Extrativista Chico Mendes, no Acre, considerada pelo governo brasileiro modelo de desenvolvimento sustentável. Diz ela que várias famílias de extrativistas acabaram engrossando a periferia de Rio Branco como penalidade infringida pelo IBAMA por abrirem pequenos roçados em meio à floresta para o cultivo de subsistência. A pesquisadora critica duramente as políticas ambientais geridas por organismos internacionais e pelos órgãos ambientais do governo, que desejam recriar uma Amazônia romantizada.

Entre os anos 1950 e meados dos anos 1980, Golbery do Couto e Silva (1967) escreveu livros e artigos demonstrando que a ocupação do espaço amazônico ocorria a partir do Rio Amazonas e, sobretudo, pelas bordas da floresta, permitindo que mais brasileiros vindos do Centro-Sul colonizassem a região. Essa área de ocupação humana mais intensa e permanente nas bordas da floresta é o que hoje as ONGs internacionais, a grande mídia e o Ministério do Meio Ambiente rotulam de "Arco de Fogo", num conceito nada inocente como alerta a geógrafa Bertha Becker (2005).

A expansão demográfica e econômica do Centro-Sul, ainda que com menor força que no passado recente, continua empurrando as bordas da floresta cada vez mais para dentro num processo espontâneo e irrefreável. A velocidade do desmatamento diminuiu diante da negativa dos organismos financeiros internacionais de bancarem a expansão da infraestrutura física e das atividades agropecuárias em plena floresta equatorial, mas isto também tem significado a precarização da vida de milhões de pessoas que vivem nessa região. Uma grande parte do caos social e urbano que se verifica nesta faixa de terras amazônicas remete justamente a esse engessamento das políticas ambientalistas para a Amazônia, que se traduz em asfalto não reposto, na inflação de alimentos e nos níveis de violência decorrentes da falta de regulação apropriada, dentre outros.

O caráter predatório da pecuária e da mineração diminuirá com a fiscalização segundo leis adequadas, algo inexistente nos garimpos ilegais e desmatamentos clandestinos. $O$ monitoramento e o manejo ambiental envolvendo a pecuária extensiva em áreas desmatadas podem, por exemplo, ajudar na recuperação de áreas degradadas pela mineração. 
Em países como Austrália e Canadá a concessão de mineração em terras de aborígenes ocorre com a participação destes no projeto e nos lucros. Enquanto isto, no Brasil, os indígenas são levados ao garimpo ilegal com a exploração da mão de obra de seu próprio povo, em razão de políticas ambientais rígidas demais para as reservas indígenas. Portanto, parte da violência nas áreas de fronteira reside exatamente na errônea arquitetura jurídica do Estado brasileiro, que veda a propriedade privada e os benefícios do planejamento econômico aos indígenas.

\section{REFERÊNCIAS}

BECKER, B. Geopolítica da Amazônia. Estudos Avançados, São Paulo, v. 53, n. 19, p. 71 86, 2005.

CAMELY, N. Onguismo como nova geopolítica do imperialismo para a biodiversidade: um estudo sobre a Amazônia Brasileira. Revista de Geopolítica, Natal, v. 1, n. 2, p. 4-23, 2011. IBGE. Geociências. Geografia. Áreas Especiais. Cadastro de Municípios localizados na Amazônia legal. 2017. Disponível em:

<https://ww2.ibge.gov.br/home/geociencias/geografia/amazonialegal.shtm?c=2>. Acesso em: 2 jun. 2018.

SCRUTON, R. Como ser um conservador. Rio de Janeiro: Record, 2015.

SILVA, G. do C. e. Geopolítica do Brasil. Rio de Janeiro: J. Olympio, 1967.

Recebido: setembro de 2017. Aceito: junho de 2018. 